\title{
Hepatic Injury and Glutathione s-transferase Deletion Related to Antituberculosis Use: An Observational Study in Balinese Population, Indonesia
}

\author{
I. Gusti Ngurah Bagus Artana ${ }^{1,2}$, I. Gusti Ayu Artini ${ }^{1,3^{*}}$, Ida Bagus Ngurah Rai ${ }^{2}$, Ida Ayu Dewi Wiryanthini ${ }^{4}$ \\ ${ }^{1}$ Doctoral Program, Faculty of Medicine, Udayana University, Denpasar, Indonesia; ${ }^{2}$ Department of Pulmonology, Faculty of \\ Medicine, Udayana University, Denpasar, Indonesia; ${ }^{3}$ Department of Pharmacology and Therapy, Faculty of Medicine, Udayana \\ University, Denpasar, Indonesia; ${ }^{4}$ Department of Biochemistry, Faculty of Medicine, Udayana University, Denpasar, Indonesia
}

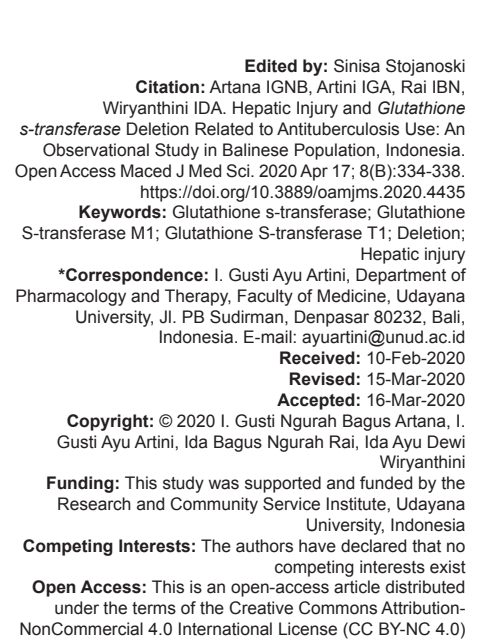

\section{Abstract}

BACKGROUND: Glutathione S-transferase (GST), together with other drug-metabolizing enzymes ( $\mathrm{N}$-acetyltransferase and cytochrome P450), plays a crucial role in the metabolism of isoniazid (isonicotinic acid hydrazide). Among five isoforms of GST, GSTM1, and GSTT1 had been proved to involve in isoniazid metabolism.

AIM: We aimed to investigate association between GST deletion and hepatic injury in the Indonesian population.

METHODS: This is a cross-sectional study. The total participants' number was 70 . Our whole blood samples were collected from adult pulmonary tuberculosis patients who received antituberculosis treatment category one in Bali. Detection for GSTM1 and GSTT1 deletion performed with the polymerase chain reaction technique using internal standard $\beta$-globin. Data analysis performed with the Chi-square test.

RESULTS: The proportion of GSTM1 null was $71.4 \%$ whereas the GSTT1 null was $34.3 \%$. The proportion of combined GSTM1 null and GSTT1 null was $22.9 \%$. There was no significant difference in liver damage incidence between GSTM1 null and wild-type $(p>0.005)$. There was also no significant difference in liver damage incidence between GSTT1 null and wild-type ( $p>0.005)$.

CONCLUSIONS: Neither GSTM1 nor GSTT1 deletion proved to be associated with liver injury regarding antituberculosis use.

\section{Introduction}

Glutathione S-transferase (GST) is widely known as one of the principal enzymes involved in the metabolism of many drugs or substances in the human body [1]. This broad class of enzymes especially takes part in phase two metabolism of drugs through catalyzing conjugation reaction to alter drugs or substances into a more polar metabolite; thus, it will be easier to excrete [1]. GST, together with other drug-metabolizing enzymes, $\mathrm{N}$-acetyltransferase (NAT), and cytochrome P450 (CYP), plays a crucial role in the metabolism of isoniazid (isonicotinic acid hydrazide) [2]. NAT enzyme takes part in isoniazid metabolism through catalyzing acetylation reaction, whereas CYP catalyzing oxidation reaction [2], [3].

GST enzyme is a soluble enzyme located in the cytosol, microsome, and mitochondria. GST enzyme in mammalian has some isoforms, including GSTA (alpha), GSTM (mu), GSTP (pi), and GSTT (theta) [4], [5]. Each isoform is encoded by a specific gene. Among the five isoforms of GST, GSTM1, and GSTT1 had been proved to involve in isoniazid metabolism [6]. GSTM1 enzyme is encoded by the GSTM1 gene located on chromosome one, while the GSTT1 enzyme is encoded by the GSTT1 gene located on chromosome 22 [6].

Some polymorphisms might potentially occur in such genes. The major type of polymorphism found in GSTM1 and GSTT1 gene is deletion [5]. Some evidence had shown that GST deletion contributed to hepatic injury induced by antituberculosis. However, there was a controversy regarding this finding in several populations [6]. Some researches represented a significant correlation between GST deletion and hepatic injury, whereas other evidence performed the opposite [5], [6]. Until now, there has been no study reporting the association between GST deletion and hepatic injury in the Indonesian population. Thus, it needs to be confirmed about this in our local population. 


\section{Methods}

\section{Samples selection and collection}

This study was an analytical observational study with a cross-sectional design. Our samples were whole blood from adult pulmonary tuberculosis patients who received antituberculosis treatment category one in Bali (which had been already collected on our previous research and preserved at Integrated Biomedical Laboratory of Medical Faculty, Udayana University). Inclusion criteria, including pulmonary tuberculosis patients in Bali, age $\geq 18$ years old, received antituberculosis treatment category one and had already signed the informed consent. Sampling method using a purposive sampling technique. The total participants' number was 70 . Our study had been approved by the Ethics Committee of Medical Faculty Udayana University/Sanglah Hospital.

\section{Detection of GSTM1 and GSTT1 deletion}

To detect the GSTM1 and GSTT1 deletion, we performed the polymerase chain reaction (PCR) technique using internal standard $\beta$-globin. PCR was set on early denaturation temperature $94^{\circ} \mathrm{C}$ (for $5 \mathrm{~min}$ ), followed by 35 cycles of denaturation $\left(94^{\circ} \mathrm{C}\right.$ for $\left.45 \mathrm{~s}\right)$, annealing $\left(55^{\circ} \mathrm{C}\right.$ for $\left.45 \mathrm{~s}\right)$, and elongation $\left(72^{\circ} \mathrm{C}\right.$ for $45 \mathrm{~s})$. Finally, the PCR temperature was ended with the final elongation at $72^{\circ} \mathrm{C}$ for five min. In the end, we identified the PCR product by identifying the fragment length for each gene: $268 \mathrm{bp}$ for the $\beta$-globin gene; 215 bp for the GSTM1 gene; and 968 bp for GSTT1 gene. The forward and reverse primer for each gene was represented in Table 1.

Table 1: Forward and reverse primer for each gene

\begin{tabular}{lll}
\hline Gene & Forward primer & Reverse primer \\
\hline B-globin & 5'-GAA GAG CCA AGG ACA GGT AC-3' & 5'-CAA CTT CAT CCA CGT TCA \\
& & CC-3' \\
GSTM1 & 5'-CTG CCC TAC TTG ATT GAT GGG-3' & 5'-CTG GAT TGT AGC AGA TCA \\
& & TGC-3' \\
GSTT1 & 5'-CTC CCT ACT CCA GTAACT CCC & 5'-CTG GTC ATG GTC TCT ATG \\
& GAC T-3' & CAAAAG A-3' \\
\hline
\end{tabular}

\section{Assessment of liver injury}

Hepatic injury was identified from the concentration of transaminase enzymes (including aspartate aminotransferase and alanine aminotransferase [ALT]) that had been assessed on our previous research. The transaminase level was measured with spectrophotometry technique. Hepatic injury incidence was categorized into two groups: With hepatic injury (at least one transaminase enzyme showed abnormal concentration) and without hepatic injury. The normal ranges of ALT and AST in the Indonesian population are $<31 \mathrm{U} / \mathrm{L}$ and $<45 \mathrm{U} / \mathrm{L}$, respectively.

\section{Data analysis}

Our data were analyzed with statistical software. The comparison of hepatic injury between GSTM1 or GSTT1 null and wild-type was analyzed using the Chi-square test. $p<0.05$ was considered as statistically significant.

\section{Results}

\section{Subject characteristics}

Of the total samples, most subjects were male and age above 30 years old (Table 2). Only $5.7 \%$ of subjects were alcoholics. There was no comorbid disease (including liver and kidney disease). Mostly no other medication taken by subjects.

Table 2: Subject characteristics

\begin{tabular}{ll}
\hline Characteristics & $\mathrm{n}(\%)$ \\
\hline Sex & \\
Male & $40(57.1)$ \\
Female & $30(42.9)$ \\
Age & \\
$\quad<30$ years old & $32(45.7)$ \\
$\geq 30$ years old & $38(54.3)$ \\
Initial AFB status & $42(60.0)$ \\
$\quad$ Positive & $28(40.0)$ \\
$\quad$ Negative & $4(5.7)$ \\
Alcohol consumption & $66(94.3)$ \\
$\quad$ Yes & \\
No & $0(0.0)$ \\
Comorbid disease & $70(100.0)$ \\
$\quad$ Yes & $14(20.0)$ \\
$\quad$ No & $56(80.0)$ \\
Other medication & \\
Yes & \\
No &
\end{tabular}

\section{The Pattern of GSTM1 and GSTT1 Genotype}

The dominant genotype pattern for GSTM1 was null-type, whereas GSTT1 was wild-type (Table 3). The proportion of GSTM1 null was $71.4 \%$, whereas the GSTT1 null was $34.3 \%$. The majority of our samples had a combination of GSTM1 null and GSTT1 wild-type. The proportion of combined GSTM1 null and GSTT1 null was $22.9 \%$.

Table 3. The pattern of GSTM1 and GSTT1 genotype

\begin{tabular}{ll}
\hline Genotype & $\mathrm{n}(\%)$ \\
\hline Genotype GSTM1 & \\
Null (-) & $50(71.4)$ \\
Wild type (+) & $20(28.6)$ \\
Genotype GSTT1 & \\
Null (-) & $24(34.3)$ \\
Wild type (+) & $46(65.7)$ \\
GSTM1 and GSTT1 combination & \\
GSTM1 (-) GSTT1 (-) & $16(22.9)$ \\
GSTM1 (-) GSTT1 (+) & $34(48.6)$ \\
GSTM1 (+) GSTT1 (-) & $8(11.4)$ \\
GSTM1 (+) GSTT1 (+) & $12(17.1)$ \\
\hline GSTM1: Glutathione s-transferase M1; GSTT1: Glutathione s-transferase T1.
\end{tabular}




\section{Hepatic injury incidence in GSTM1 and GSTT1 deletion}

As many as five subjects represented enhanced transaminase levels. There was no significant difference in liver damage incidence between GSTM1 null and wild-type $(p>0.05)$. There was also no significant difference in liver damage incidence between GSTT1 null and wild type $(p>0.05)$. There was no significant difference in liver damage incidence between combined GSTM1 and/or GSTT1 null and GSTM1 wild-type/ GSTT1 wild-type ( $p>0.05)$ (Table 4).

Table 4: Hepatic injury incidence according to GSTM1 and GSTT1 deletion

\begin{tabular}{llll}
\hline Genotype & \multicolumn{2}{l}{ Hepatotoxic } & $\mathrm{p}$ \\
\cline { 2 - 3 } & Yes n (\%) & No n (\%) & \\
\hline GSTM1 & $6(12.0)$ & $44(88.0)$ & \multirow{2}{*}{0.610} \\
$\quad$ Null & $4(20.0)$ & $16(80.0)$ & \\
$\quad$ Wild type & $4(16.7)$ & $20(83.3)$ & \multirow{2}{*}{1.000} \\
$\begin{array}{l}\text { GSTT1 } \\
\quad \text { Null }\end{array}$ & $6(13.0)$ & $40(87.0)$ & \\
$\quad$ Wild type & $6(10.3)$ & $52(89.7)$ & \multirow{2}{*}{0.195} \\
GSTM1, GSTT1 & $4(33.3)$ & $8(66.7)$ & \\
$\quad$ GSTM1 null and/GSTT1 null & GSTM1 WT and GSTT1 WT & & \\
GSTM1: Glutathione s-transferase M1, GSTT1: Glutathione s-transferase T1, WT: Wild-type. &
\end{tabular}

\section{Discussions}

For years, isoniazid has proved to be the primary antituberculosis drug that contributes to hepatic injury in tuberculosis patients. Approximately 10-20\% of tuberculosis patients who received isoniazid will lead to an increase of transaminase enzyme, especially ALT, as many as three times the normal upper limit [2], [3].

One of the possible factor influences hepatic injury induced by antituberculosis is genetic variation. Specifically for isoniazid, genetic variations that mostly related to liver damage are genetic variations on the drug-metabolizing enzymes, including NAT2, CYP, GSTM1, and GSTT1 [4], [6].

GST, as the primary enzyme, plays a role in phase two metabolism of isoniazid, might demonstrate deletion, thus might result in enhanced risk of liver damage in tuberculosis patients who are taking antituberculosis. On isoniazid metabolism, GST enzymes detoxify the toxic metabolites of isoniazid into the non-toxic and excretable form [7], [8].

Our results demonstrated that the proportion of null-type GSTM1 was higher than wildtype GSTM1 (71.4\% vs. $28.6 \%)$. This was similar to evidence showed on a study in China, Japan, Thailand, and Turkey. The proportion of GSTM1 null in China, Japan, Thailand, and Turkey was 57.9\%, 53.5\%, 60\%, and $72 \%$ [9]. However, some studies revealed different results. The proportion of null-type GSTM1 on research done by Teixeira et al. [10] and Santos et al. [11] in Brazil, and also by Gupta et al. [12] in India, was lower than wild-type GSTM1. The difference is highly related to the race variation among populations.

However, our finding revealed that there was no significant difference in hepatic damage incidence related to antituberculosis between wild-type and nulltype of GSTM1. Our result was similar to several studies in China, India, Brazil, and Korea [12], [13], [14], [15]. Some studies demonstrated contrary findings. Some studies stated that GSTM1 null-type increased the risk of hepatic injury related to antituberculosis use [16], [17]. Meta-analysis reports supported a significant correlation between GSTM1 deletionandhepaticinjuryintuberculosis who were taking antituberculosis [8], [18], [19], [20]. A variation on the association of GST deletion with hepatic injury might particularly be influenced by a variation on race and ethnicity. Our finding was similar to other studies conducted in Asian countries, including India, China, and Korea. Moreover, there are also some other important enzymes responsible for isoniazid metabolism, namely, CYP and NAT2. Genetic variation on these genes might largely contribute to hepatic injury related to antituberculosis use.

Regarding our finding for the GSTT1 gene, the wild-type GSTT1 was the dominant genotype in our samples. The proportion of GSTT1 null-type in our research was $34.3 \%$. This was consistent with the proportion of GSTT1 null-type in India (11.8\%) and Brazil (22\%) [11], [12].

There was no significant difference in liver damage proportion between wild-type and null-type of GSTT1 represented in our study. Several studies reported similar findings. Deletion on GSTT1 reported no significant association with liver damage induced by antituberculosis in other Asian populations, namely, Chinese and Indian [10], [13], [16], [21], [22], [23]. This supported the concept that genetic variation mostly influenced by race or ethnicity.

Some meta-analysis also revealed that there was no significant difference in hepatic injury proportion between GSTT1 nulland wild-typeintuberculosis patients who were taking antituberculosis [8], [18], [19], [20]. In East Asian, GSTT1 was also not considered as a risk factor for hepatic injury related to antituberculosis administration [8], [18], [19], [20].

Our finding was different from evidence in Caucasian, India and Brazil. In the Caucasian population, GSTT1 deletion enhanced the risk of hepatic damage related to antituberculosis about 2.6 times, whereas in Indian, about 2.92 times [12]. Research conducted by Forestiero et al. [17] in Brazil reported a similar finding. It was revealed that GSTT1 null was significantly related to a mild increase of transaminase enzyme on tuberculosis patients who received antituberculosis. A report by Santos et al. in Brazil also supported this finding [18].

Regarding combined deletion on GSTM1 and GSTT1, our study found that there was no significant 
difference in hepatic damage incidence between combined GSTM1 null/GSTT1 null and wild-type. Our result supported evidence performed by Chaterjee et al. [14] and Yang et al. [20]

Opposite results were stated by Gupta et al. [12] and Singla et al. [24]. Combined deletion on GSTM1 and GSTT1 gene was proved to be represented a significantly higher risk of hepatic damage induced by antituberculosis in the Indian population. The opposite result possibly related to the different proportion of GSTM1 deletion between our study and study conducted by Gupta et al. In our study, GSTM1 null was the dominant genotype for GSTM1, whereas in a study conducted by Gupta et al., GSTM1 wild-type was the dominant genotype for GSTM1 in the study population [12].

Isoniazid is a prodrug that should be converted first into acetyl isoniazid (catalyzed by NAT enzyme) and hydrazine. Hydrazine and acetyl isoniazid subsequently will be changed into acetyl hydrazine and finally forms diacetylhydrazine. Acetyl hydrazine is also metabolized by the CYP2E1 enzyme, forming toxic metabolite which then will be detoxified by GST before excreted from our body. Deletion on GSTM1 and GSTT1 might result in a decrease or loss of GST enzyme activity. This might lead to liver damage following the increase of isoniazid toxic metabolites. Avariation on the association of GST deletion with hepatic injury might particularly be influenced by a variation on race and ethnicity [3], [4], [5], [6].

\section{Conclusions}

The majority of our subjects showed nulltype GSTM1 and wild-type GSTT1. Neither GSTM1 nor GSTT1 deletion proved to be associated with liver injury induced by antituberculosis. Combined GSTM1 null/GSTT1 null also revealed no significant correlation with hepatic damage related to antituberculosis use.

\section{References}

1. Lv X, Tang S, Xia Y, Zhang Y, Wu S, Yang Z, et al. NAT2 genetic polymorphisms and antituberculosis druginduced hepatotoxicity in Chinese community population. Ann Hepatol. 2012;11(5):700-7. https://doi.org/10.1016/ s1665-2681(19)31446-2

PMid:22947533

2. Bose PD, Sarma MP, Medhi S, Das BC, Husain SA, Kar P. Role of polymorphic $\mathrm{N}$-acetyl transferase2 and cytochrome P4502E1 gene in antituberculosis treatment-induced hepatitis. J Gastroenterol Hepatol. 2011;26(2):312-8. https://doi. org/10.1111/j.1440-1746.2010.06355.x

PMid:21261721

3. Arbex MA, Varella MC, deSiqueira HR, de Mello FA.
Antituberculosis drugs: Drug interaction, adverse effects, and use in special situations. Part 1: First-line drugs. J Bras Pneumol. 2010;36(5):626-40.

PMid:21085830

4. Stimimann G, Kessebohm K, Lauterburg B. Liver injury caused by drugs: An update. Swiss Med Wkly. 2010;140:w13080. https://doi.org/10.4414/smw.2010.13080

PMid:20927685

5. Chen M, Suzuki A, Borlak J, Andrade RJ, Isabel M, Lucena MI Drug-induced liver injury: Interactions between drug properties and host factors. J Hepatol. 2015;63(2):503-14. https://doi. org/10.1016/j.jhep.2015.04.016

PMid:25912521

6. Huang Y. Recent progress in genetic variation and risk of antituberculosis drug-induced liver injury. J Chin Med Assoc. 2014;77(4):169-73. https://doi.org/10.1016/j.jcma.2014.01.010 PMid:24593909

7. Oh RC, dan Hustead TR. Causes and evaluation of mildly elevated liver transaminase levels. Am Fam Physician. 2011;84:1003-8.

8. Cai L, Cai M, Wang M, Xu Y, Chen W, Qin S, et al. Meta-analysisbased preliminary exploration of the connection between atdili and schizophrenia by GSTM1/T1 gene polymorphisms. PLoS One. 2015;10(6):e0128643. https://doi.org/10.1371/journal. pone. 0128643

PMid:26046920

9. Wang T, Yu HT, Wang W, Pan YY, He LX, Wang ZY. Genetic polymorphisms of cytochrome 450 and glutathione s-transferase associated with antituberculosis drug-induced hepatotoxicity in Chinese tuberculosis patients. J Int Med Res. 2010;38(3):977986. https://doi.org/10.1177/147323001003800324 PMid:20819434

10. Teixeira RL, Morato RG, Cabello PH, Munizz LM, Moreira AS, Kritski AL, et al. Genetic polymorphisms of NAT2, CYP2E1 and GST enzymes and the occurrence of antituberculosis drug-induced hepatitis in Brazilian TB patients. Mem Inst Oswaldo Cruz. 2011;106(6):716-724. https://doi.org/10.1590/ s0074-02762011000600011

PMid:22012226

11. Santos EA, Goncalves JC, Fleury MK, Kritski AL, Oliveira MM, Velasque LS, et al. Relationship of anti-tuberculosis druginduced liver injury and genetic polymorphisms in CYP2E1 and GST. Braz J Infect Dis. 2019;23(6):381-7. https://doi. org/10.1016/j.bjid.2019.09.003

PMid:31697922

12. Gupta VH, Singh M, Amarapurkar DN, Sasi P, Joshi JM, Baijal R, et al. Association of GST null genotypes with antituberculosis drug induced hepatotoxicity in Western Indian population. Ann Hepatol. 2013;12(6):959-65. https://doi.org/10.1016/ s1665-2681(19)31302-x

PMid:24114827

13. Tang SW, LvXZ, Zhang Y, Wu SS, Yang ZR, Xia YY, et al. CYP2E1, GSTM1andGSTT1 genetic polymorphisms and susceptibility to antituberculosis drug-induced hepatotoxicity: A nested casecontrol study. J Clin Pharm Ther. 2012;37(5):588-93. https://doi. org/10.1111/j.1365-2710.2012.01334.x PMid:22335459

14. Chatterjee S, Lyle N, Mandal A, Kundu S. GSTT1 and GSTM1 gene deletions are not associated with hepatotoxicity caused by antitubercular drugs. J Clin Pharm Ther. 2010;35(4):465-70. https://doi.org/10.1111/j.1365-2710.2009.01101.x PMid:20853551

15. Kim SH, Yoon HJ, Shin DH, Park SS, Kim YS, Park JS, et al. GSTT1 and GSTM1 null mutations and adverse reactions induced by antituberculosis drugs in Koreans. Tuberculosis 


(Edinb). 2010;90(1):39-43. https://doi.org/10.1016/j.
tube.2009.12.001
PMid:20036620

16. Rana SV, Sharma SK, Ola RP, Kamboj JK, Malik A, Morya RK, et al. N-acetyltransferase 2, cytochrome p4502e1 and glutathione s-transferase genotypes in antitubercular treatmentinduced hepatotoxicity in North Indians. J Clin Pharm Ther. 2014;39(1):91-6. https://doi.org/10.1111/jcpt.12105 PMid:24188272

17. Forestiero FJ, Cecon L, Hirata MH, de Melo FF, Cardoso RF, Cerda A, et al. Relationship of NAT2, CYP2E1 and GSTM1/ GSTT1 polymorphisms with mild elevation of liver enzymes in Brazilian individuals under anti-tuberculosis drug therapy. Clin Chim Acta. 2013;415:215-9. https://doi.org/10.1016/j. cca.2012.10.030

PMid:23099118

18. Cai Y, Yi JY, Zhou CH, Shen XZ. Pharmacogenetic study of drug-metabolizing enzyme polymorphism on the risk of antituberculosis drug-induced liver injury: A meta-analysis. PLoS One. 2012;7(10):e47769. https://doi.org/10.1371/journal. pone.0047769

PMid:23082213

19. Li C, Long J, Hu X, Zhou Y. GSTM1 and GSTT1 genetic polymorphisms and risk of anti-tuberculosis drug-induced hepatotoxicity: An updated meta-analysis. Eur J Clin Microbiol Infect Dis. 2013;32(7):859-68. https://doi.org/10.1007/ s10096-013-1831-y

PMid:23377313

20. Yang S, Hwang SJ, Park JY, Chung EK, Lee JI. Association of genetic polymorphisms ofCYP2E1,NAT2,GSTandSLCO1B1 with the risk of antituberculosis drug-induced liver injury: A systematic review and meta-analysis. BMJ Open. 2019;9(8):e027940. https://doi.org/10.1136/bmjopen-2018-027940

PMid:31375612

21. Feng FM, Guo M, Chen Y, Li SM, Zhang P, Sun SF, et al. Genetic polymorphisms in metabolic enzymes and susceptibility to anti-tuberculosis drug-induced hepatic injury. Genet Mol Res. 2014;13(4):9463-71. https://doi.org/10.4238/2014 november.11.11

PMid:25501156

22. Xiang Y, Ma L, Wu W, Liu W, Li Y, Zhu X, et al. The incidence of liver injury in uyghur patients treated for tb in xinjiang uyghur autonomous region, China, and its association with hepatic enzyme polymorphisms NAT2, CYP2E1, GSTM1 and GSTT1. PloS One. 2014;9(1):e85905. https://doi.org/10.1371/journal. pone.0085905

PMid:24465778

23. Liu $F$, Jiao $A$, Wu $X$, Zhao $W$, Yin $Q$, Qi $H$, et al. Impact of glutathione s-transferase M1 and T1 on anti-tuberculosis druginduced hepatotoxicity in Chinese pediatric patients. PLoS One. 2014;9(12):e115410. https://doi.org/10.1371/journal. pone. 0115410

PMid:25525805

24. Singla N, Gupta D, Birbian N, Singh J. Association of NAT2, GST and CYP2E1 polymorphisms and anti-tuberculosis druginduced hepatotoxicity. Tuberculosis (Edinb). 2014;94(3):293-8. https://doi.org/10.1016/j.tube.2014.02.003

PMid:24637014 